\title{
Local Wisdom on Town Square of Ponorogo
}

\section{Wahyuni Eka Sari ${ }^{* *}$}

${ }^{1}$ Magister of Architecture, University of Brawijaya, Malang, Indonesia

Corresponding Author: sariekawahyuni@gmail.com

\begin{tabular}{|c|c|}
\hline & Abstract \\
\hline $\begin{array}{l}\text { Keywords: } \\
\text { Local wisdom; } \\
\text { Ponorogo Regency } \\
\text { Square; Public } \\
\text { Open Space; Town } \\
\text { Square }\end{array}$ & $\begin{array}{l}\text { The town square that we know is open space for the public. The square is often found in } \\
\text { almost all cities in Indonesia. The square is a part of the city that can be used as a city } \\
\text { park. The town square in Ponorogo Regency is a square that functions as a public open } \\
\text { space that is visited by many Ponorogo residents themselves and from outside Ponorogo. } \\
\text { Many activities are carried out in the square. Activities such as selling, gathering, mutual } \\
\text { interaction between individuals, exercise are carried out every day. In addition, cultural } \\
\text { activities or official government activities are also carried out in this square. Ponorogo } \\
\text { Square can be a unifier for Ponorogo residents themselves. The purpose of this study was } \\
\text { to find out how the local wisdom of the Ponorogo Regency square that currently exists. } \\
\text { The method used is descriptive analysis method using exposure from the results of field } \\
\text { surveys. The results of this study are in the form of local wisdom conditions formed from } \\
\text { the Ponorogo Regency square. }\end{array}$ \\
\hline
\end{tabular}

@ 2017 The Authors. Published by GKAK UNMER Malang

*Corresponding Author: sariekawahyuni@gmail.com 


\section{Introduction}

Ponorogo Regency is known as the Reog culture. The Reog culture has become a distinctive characteristic of Ponorogo Regency since a long time ago. Ponorogo residents have their own pride in this culture. Many performances by Reog in Ponorogo were carried out to preserve the ancestral cultural heritage. It is a local wisdom that is only owned by the people of Ponorogo Regency. Reog performances will be found in many annual events or special events that are celebrated. But besides Reog, there is still a lot of local wisdom from Ponorogo Regency that can still be studied.

The Ponorogo community still adheres to tradition and culture. Many cultural activities are still carried out. This traditional activity is still preserved in honor of the ancestors. In some areas there are still many activities such as Bersih Desa, larung sesaji, even mutual cooperation (gotong royong) can become a local wisdom that cannot be avoided from the Ponorogo community. Not only the people, but also the Government is still trying to support all these cultural activities. It's like doing an annual ritual to commemorate the anniversary of Ponorogo Regency at the time of Grebeg Suro.

Grebeg Suro is an annual event that is highly anticipated by Ponorogo residents. The series of various events and activities are held for a full month. This is where the Ponorogo Regency Government will revive all existing activities, including cultural activities. The Grebeg Suro will begin with the larung sesaji, cultural festival, the National Reog Festival and so on. In addition to the reog festival, there are many other activities such as the gajah-gajahan culture festival which is also an art from Ponorogo.

The main activities held will be held in the Ponorogo Regency Town square. Ponorogo Regency Square is a public space dedicated to Ponorogo resident's visitors and outside Ponorogo. The square as an open space that can be accessed all groups. (Carr, Stephen, Francis, Rivlin, \& Stone, 1992) in (Putra, Azwir, Octaviany, \& Nilamsuci, 2015) explain that open space can be interpreted as a place that accommodates all activities, can also be a gathering place for activities, which is temporary or repeated periodically.

\section{Square as a Public Open Space}

The town square is a public open space in an area. Almost all cities in Java will have a town square. It is a space that will be accessed by anyone. Many functions can be accommodated from the town square. According to the Minister of Public Works Regulation Number: 05 / PRT / M / 2008 in (Siahaan, 2010) as public open spaces are:

1. as the procurement of macro open space

2. as a climate controller for smooth air circulation

3. as a shade

4. as a oxygen producer

5. as rainwater absorbent

6. as a wildlife habitat provider

7. as a pollutant absorber

8. as a windbreak 
The town square as a public open space can provide many benefits both for humans and environment. The town square as a place for interacting citizens will be very functioning to revive the activities found in the square. The town square will not only be an empty open space, but there are various kinds of activities. Activities that occur all the time and continuously will benefit the life of the city. The city will not be quiet with these activities.

The square is seen as an empty space. Empty space is a free place to interact with the community. This square is located in a city and becomes a marker for the city. Utilization of the square is open and free. In its activities the actors in the square are managers and visitors, both from outside and inside the city (Anisya \& Muta'ali, 2015).

Public open space can also be an icon of a city. The town square is a central point of a city. It is becomes a meeting point which can be a sign of an area. It can also be the center of community activities. Many activities can be done in the town square. The activity of interaction between citizens is one that is mostly done in the square as an open space. Releasing fatigue and chatting or jesting is also a routine.

Open space becomes the center of activities that can be sustainable. All instructional activities can be carried out in an open space. Social functions and ecological functions can be contained in the square (Hakim, 1987). Both functions relate to each other. Open space social function of: 1. Play and sports area; 2. Free area to release fatigue; 3. place of social interaction; 4 . Temporary shelter; 5 . Places to enjoy fresh air; 6. Transition area; 7. as a marker between buildings. Ecological functions that can be accommodated: 1 . as a place for air to change; 2. Rainwater absorption site; 3 . Place for flood prevention; 4. Places to maintain existing ecosystems; 5 . Increase the aesthetic value of the building.

Open space according to accommodated activities, can be grouped into 2, namely: 1 . Open open space in the event of an activity contained within it. Activities that can be accommodated include playing, sports, ceremonies, communicating, walking, greening the environment, and if on the riverbank can be as a place of recreation; 2. Passive open space is a space where there is no activity or no activity occurs in it. Passive open space can function as greening the environment or clean air source (Hakim, 1987)

\section{Activities in Ponorogo Regency Square}

Ponorogo Regency Square is a marker point for Ponorogo Regency and is located in the city center. Ponorogo Regency Square with an area of about 3.1 hectares surrounded by activity centers as well as public facilities, making it very easy to reach both from within the city and outside the city. Ponorogo Kabuapten square boundaries:

North : Ponorogo Regency Regent Office

East : Trading

South : Trading

West : Ponorogo Agung Mosque 


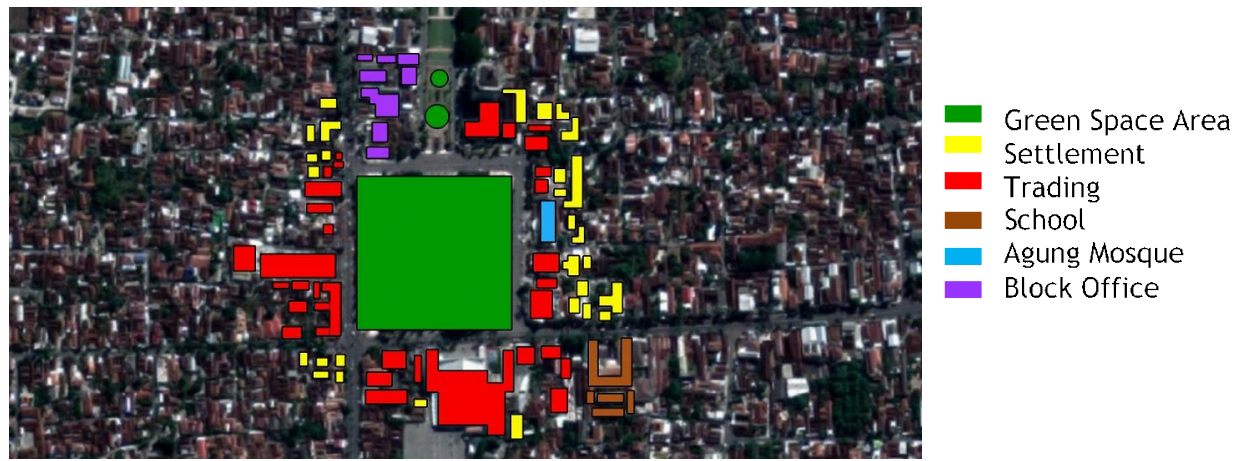

Figure 1. Ponorogo Regency Square(Source: Google Earth)

The physical conditions found in Ponorogo Regency square are seen in the land use around the square. It is a shopping area. The north side is the Ponorogo regency office area. There is the Agung Mosque to the west. The Javanese traditional concept who believe the existence of Catur Tunggal concept on the town square. The concept of the Catur Tunggal is the square, the mosque, the Regency hall, and the Karisidenan office. North of the main square is the Regent's house, and the western is a mosque. (Handinoto \& Soehargo, 1996).

In the Ponorogo Regency square, there are several facilities that support community activities. There is a large pedestrian area that can facilitate pedestrians, both in the afternoon and at night. The road around the square is the main road which wide enough for vihicled. In addition there are also several shades such as vegetation or pergola around it. This pergola is accompanied by a seat to relax. Trash facilities are available for cleanliness around it.
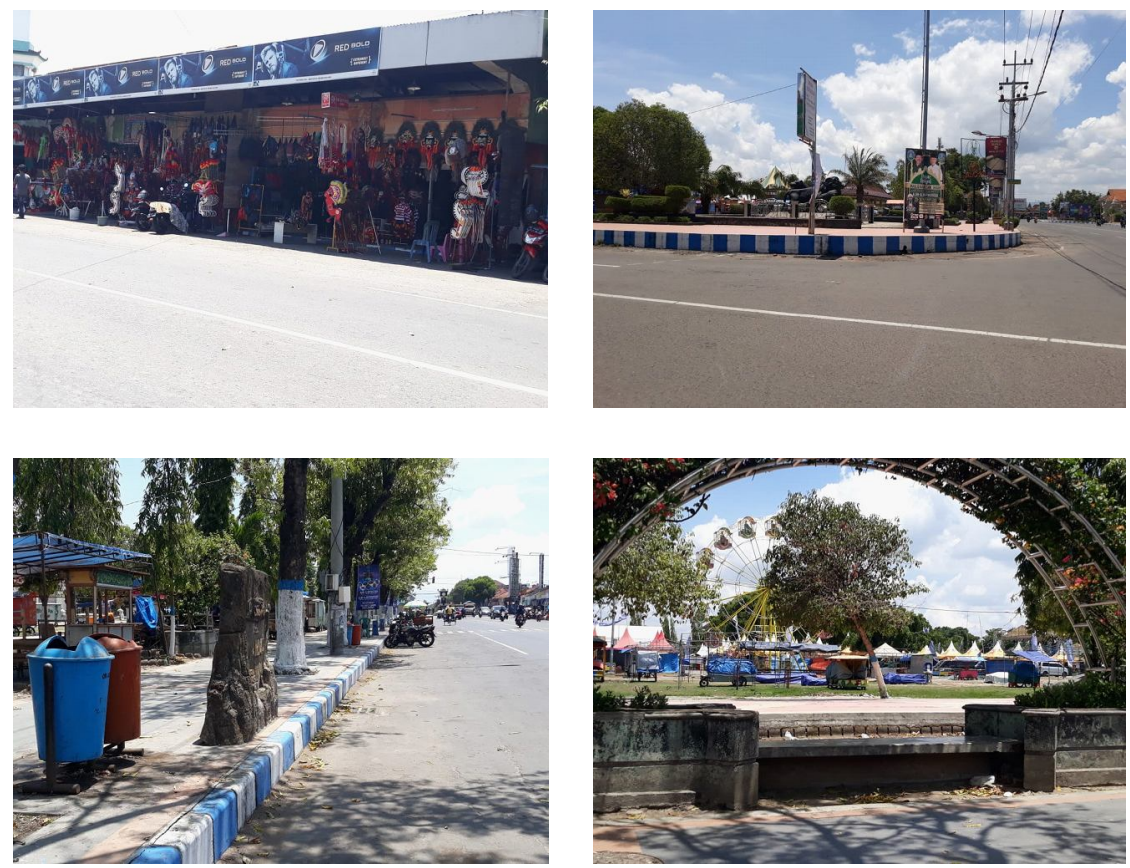

Fiigure 2. The Condition Arround the Ponorogo Regency Square 
The advantages of the Ponorogo Regency square are in the city center of Accessibility which is very easy to reach from various parts of Ponorogo and as a city icon. The place is very strategic; access that can be passed is a highway with easy and smooth pavement. There are four sides that can be accessed to the town square. From the west it can be accessed from Central Java, from the north is Madiun, from the East Trenggalek Regency while from the south it can be accessed by Pacitan Regency. There is a traffic sign that can lead to the town square.

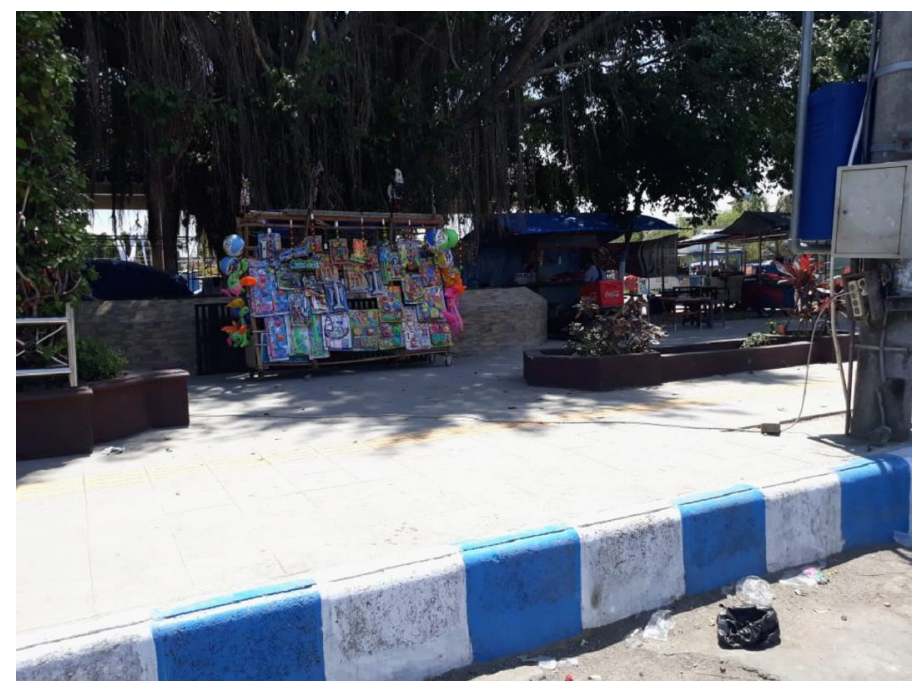

Figure 3. Cadger Conditions in Ponorogo Regency Square

Activities held in Ponorogo Regency square occur from morning to midnight. At one time the activity on this square will run for 24 hours. Daily activities such as general activities will take place every day continuously. The square will never be quiet because there are always visitors coming. The activities carried out vary greatly. Activities that are normally carried out are interaction activities, such as chatting or just sitting back while enjoying a cup of coffee.
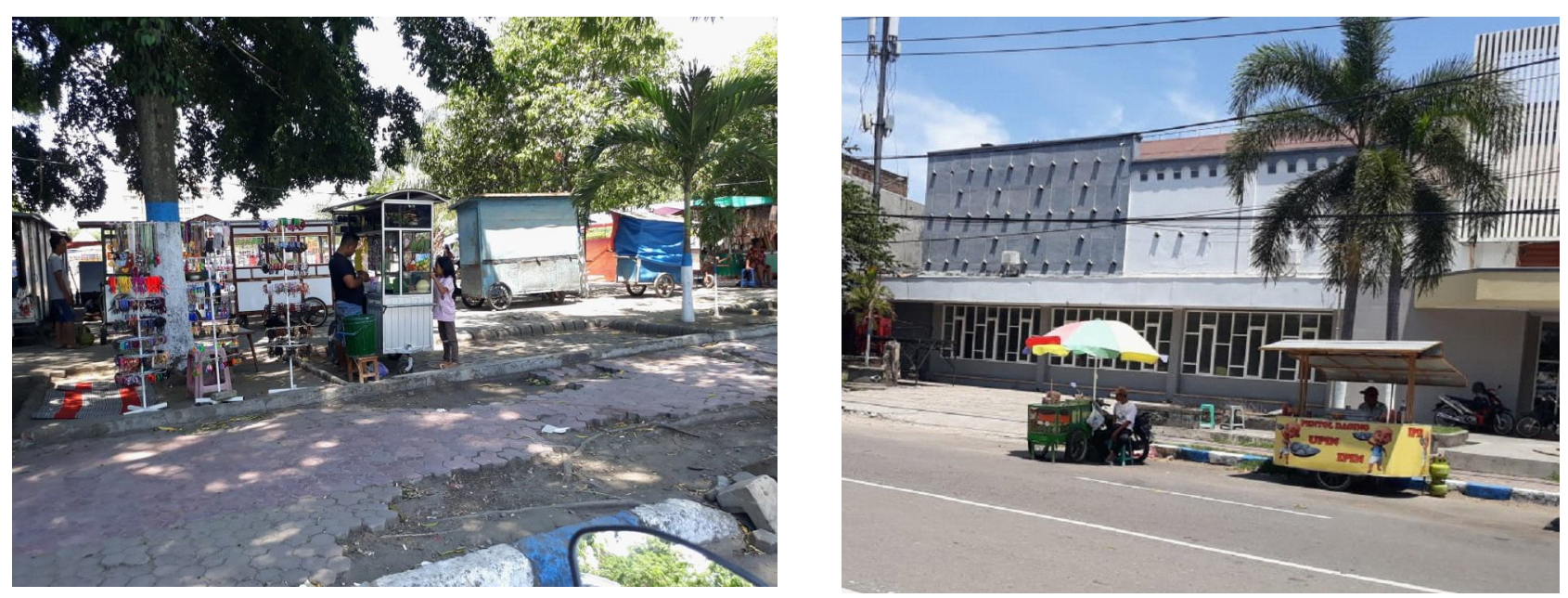

Figure 4. the interaction of sellers and buyers in Ponorogo Regency Square in the afternoon 
The social interaction in the Ponorogo Regency square is a continuous daily activity. this interaction can occur from many things, not only chatting casually but also on buying and selling activities. Trade is the main thing that can be observed from all activities that exist in the Ponorogo Regency square. This is supported by the Government which sets the square as an area of economic development with the existence of Cadger.

The night activities that took place at the Ponorogo Regency square were buying and selling activities that the differences with day and morning that if at night there will be more Cadger who lined up offering their wares. Night activities will begin around after Asr or around $3 \mathrm{pm}$. The cadgers will start holding snacks around the square. The area with the most street cadger is in the north. Many kinds of products sold are dominated by food sellers who are most purchased by residents. Various kinds of rice cakes are sold such as fried sticks, grilled sausages, fruit salad, roasted corn, sweet corn, juice, cheese cassava, boiled peanuts, and heavy foods like fried rice and chicken noodles. There are only those to be take a way, some open outlets to sit near the seller.

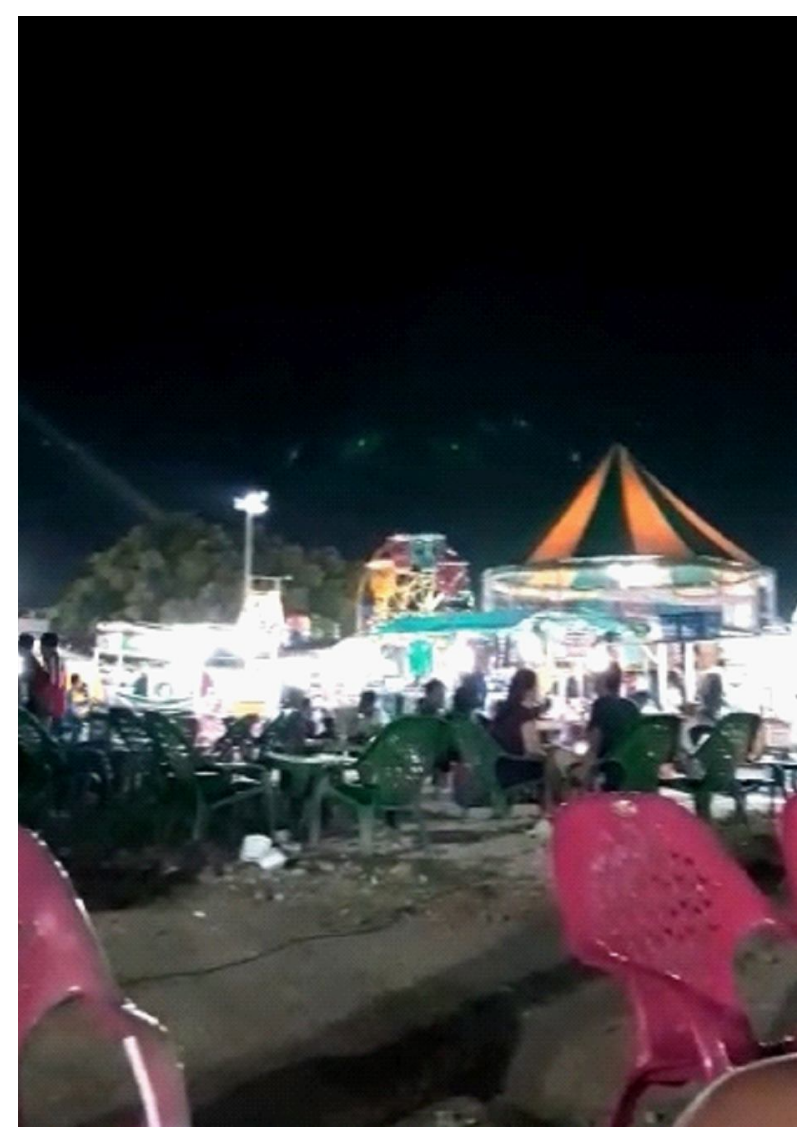

Gambar 5. The Cadger Situation on the Night in Ponorogo Regency Squre 


\section{Local Wisdom on Town Square of Ponorogo}

Wahyuni Eka Sari ${ }^{*}$

Other activities can be accommodated in the Ponorogo Regency square. Common activities that can be enjoyed by visitors both from inside and outside the region held every year. This activity was held by the Government of Ponorogo District as the manager of the square. They held this event to introduce city icons to outside audiences. This is for promotional purposes.

The activity held by the government is an annual event. The annual event series takes place throughout the year located in the square. Start the annual National Reog Festival, Ramadhan night market, Eid al-Fitr, August 17 commemoration, and also the Grebeg Suro event to commemorate the anniversary of Ponorogo Regency. This program is routine and continues until now.

The National Reog Festival presents the public as spectators both from inside and outside the city. The participants of the event were Reog groups from all over Indonesia. The Reog Festival will be held every night with a certain vulnerable time. this is held at Grebeg Suro. In this activity many cadger will sell their wares. They will fill the entire square area, and it will look like a night market. Many people will gather to enjoy the festival or just take a walk or relax enjoying the night atmosphere.

Another annual activity which is accommodated in the town square is the cadger event when Lebaran will take place that occurs from morning to night. Not only sellers and buyers, there are also rides like the Ferris wheel, mini jet coater, carousel or train that runs around the square area. The existing night market occurred from the beginning of Ramdhan until it ended when the Eid was finished. Interaction activities occur when there is an interaction between seller and buyer, or between visitors. The unique thing about this cadger is that sellers sell their merchandise not only from within the city, but also many who come from outside the city such as Solo, Ngawi, and also Magetan.

The 17 Agustusan activities is also a main activity carried out every year. Routine activities carried out are Republic of Indonesia Independence Day held in the morning and followed by events such as rowing races, car decorating competitions, or walking competitions. This activity was carried out with the participation of all residents and communities of Ponorogo Regency. In the afternoon a flagbreaking ceremony will be held. One thing that has never been separated from the Ponorogo Regency square is that there are still interactions and buying and selling activities from cadger and also from people who come to see.

The town square is an integral part of the Ponorogo community. It is one of the destinations must be visited, either at an event or just stop by. So that, it can be an asset for citizens and government that cannot avoided. It becomes a city tourist destination that cannot be eliminated. The square can be as an entertainer or as a means of recreation and destination for all people. Tourism described by (Muntiaha, Egam, \& Waani, 2018) is tourism or activities that are located in urban areas with several elements, namely attractions, amenities, accessibility. Ansilari, and community involvment.

Ponorogo Regency which is famous for Reog can also be known through its square. Activities that characterize Ponorogo Regency every year will be remembered and made an impression on everyone. Activities that can be enjoyed on this square will be a tourist attraction. It didn't feel like going to Ponorogo without tasting the annual activities that are usually held in the square. The square as well as a place for cultural people, happens all the time. Not only from the Reog Festival activities, but the cultures created from daily activities can be accommodated. This continuous culture can become a local wisdom in the Ponorogo Regency square. 


\section{Conclussion}

The square is a part that cannot be separated from the activities of the Ponorogo community. Micro-scale activities and macro-scale activities are part of community activities. The daily activities that can be carried out in the square are very influential on the sustainability of the function and meaning of the square. The square which is generally a public open space can be a social cultural forum with other additional benefits. The benefits of the square can be seen by being able to accommodate community interaction activities. Interaction that has become a main activity is the interaction between sellers and buyers of cadger in the square every day. Cadgers in the square are a special attraction. The buying and selling activity of street vendors takes place every time of the year and continues. In buying and selling activities there are interactions that become a cultural value that follows. Culture is not only from art activities, but from daily activities that cannot be separated from human life. This culture is a local wisdom held by the Ponorogo Regency square. Activities that occur every day provide benefits not only for the community, cadgers, but also for the government. Other supporting activities held by the government are annual activities in Ponorogo culture, namely the Reog Festival at Grebeg Suro, night market activities during Eid and also the 17Agustusan event. This activity was held to make the square an open space that is not only passive but also active. Cultural activities continue to occur in the form of interactions that become a local wisdom. Cadgers with all the activities of buying and selling with the community that occur every day can become part of the existing local wisdom.

\section{References}

Anisya, I., \& Muta'ali, L. (2015). Kajian Pemanfaatan Alun-alun sebagai Ruang Publik di Kota Cirebon.(The Utilization Study of the Square as a Public Room in the City of Cirebon. Indonesian Earth Journal) Jurnal Bumi Indonesia,4(4).

Carr, S., Stephen, C., Francis, M., Rivlin, L. G., \& Stone, A. M. (1992). Public space: Cambridge University Press.

Hakim, R. (1987). Unsur perancangan dalam arsitektur lansekap((Elements of design in landscape architecture); Bina Aksara.

Handinoto, \& Soehargo, P. (1996). Perkembangan kota dan arsitektur kolonial Belanda di Malang (City development and Dutch colonial architecture in Malang). Surabaya: Lembaga Penelitian dan Pengabdian kepada Masyarakat, Universitas Kristen PETRA.

Muntiaha, G. I., Egam, P. P., \& Waani, J. O. (2018). Penerapan Konsep Urban Tourism pada Perancangan Permukiman Sindulang Satu di Manado (Implementation of the Urban Tourism Concept in the Design of One Sindulang Settlement in Manado). Fraktal: Jurnal Arsitektur, Kota dan Sains, 3(1).

Putra, A. D., Azwir, M., Octaviany, V., \& Nilamsuci, R. (2015). Kajian Transformasi Bentuk dan Fungsi Alun-alun Bandung Sebagai Ruang Terbuka Publik (Study of Transformation of the Shape and Function of Bandung Square as a Public Open Space). REKA KARSA, 3(3).

Siahaan, J. (2010). Ruang Publik: Antara Harapan dan Kenyataan (Public Space: Between Hope and Reality). Diakses di http://ruang publik/Bulletin Elektronik. htm. 